\title{
HUBUNGAN PARAMETER LINGKUNGAN TERHADAP GANGGUAN KESEHATAN KARANG DI PULAU TUNDA - BANTEN
}

\author{
ENVIRONMENTAL PARAMETERS RELATIONSHIP OF CORAL HEALTH DISRUPTION \\ IN TUNDA ISLAND - BANTEN
}

\author{
Dedi $^{1)}$, Neviaty P. Zamani' ${ }^{2}$, dan Taslim Arifin ${ }^{3)}$ \\ 1) Program Studi Ilmu Kelautan, Institut Pertanian Bogor \\ 2) Departemen Ilmu dan Teknologi Kelautan, FIPK- IPB, Bogor \\ ${ }^{3)}$ Pusat Penelitian dan Pengembangan Sumberdaya Laut dan Pesisir, Badan Litbang KP-KKP
}

Diterima tanggal: 2 November 2016, diterima setelah perbaikan: 7 Februari 2017, disetujui tanggal: 14 Februari 2017

\begin{abstract}
ABSTRAK
Kondisi lingkungan dan aktivitas manusia menyebabkan terganggunya ekosistem pesisir khususnya terumbu karang. Gangguan kesehatan dan penyakit pada karang dapat terjadi karena perubahan kondisi lingkungan. Pulau Tunda merupakan pulau terluar yang berbatasandengan Teluk Jakarta dan Teluk Banten diasumsikan mendapatkan tekanan lingkungan dari pembangunan daerah tersebut. Penelitian ini mengkaji apakah parameter lingkungan memiliki hubungan dengan sebaran gangguan kesehatan karang.Survei lapangandilakukan pada Januari 2014. Pengambilan data dilakukan dengan metode transek sabuk dengan lebar $1 \mathrm{x} 1 \mathrm{~m}$ pada kedalaman berkisar $3-5 \mathrm{~m}$. Hubungan parameter lingkungan dan kelimpahan penyakit karang dianalisis dengan Principal Components Analysisdan sebaran penyakit karang dianalisis dengan Correspondent Analysis.Dari hasil pengamatan, jenis gangguan yang terdapat pada lokasi pengamatan Pulau Tunda - Banten yaitu pemutihan karang (Full, Patches, dan Stripes) sedangkan gangguan kesehatan lainnya meliputi Cots, fishbite, PR, IG, SP dan SD. Pemutihan karang bentuk Patches merupakan bentuk pemutihan karang yang banyak ditemukan dari seluruh lokasi pengamatan dengan total koloni yang terserang sebanyak 91 koloni. Gangguan kesehatan SP (Spons Over) merupakan gangguan kesehatan yang sedikit (7 koloni) ditemukan pada lokasi pengamatan.Sebaran pemutihan karang memiliki hubungan terhadap salinitas, suhu dan fosfat sedangkan gangguan kesehatan karang SD dan SP memiliki hubungan terhadap konsentrasi nitrat dan silikat.
\end{abstract}

Kata kunci: Penyakit karang, kelimpahan, Pulau Tunda.

\begin{abstract}
Environmental conditions and human activities may cause the disruption of coastal ecosystems, especially coral reefs. Health disorders and diseases of the coral often occur are due to changes in environmental conditions. Tunda Island,bounded outer islands and the Jakarta Bay and Banten Bay, is assumed to obtain environmental pressures of development of the area. This study aims to see if environmental parameters are linked to the distribution of coral health problems. Field observation was conducted in January 2014. Data collection was performed with a belt transect method with a width of $1 \times 1 \mathrm{~m}$ at depths ranging from 3-5m. Environmental parameters relationship and abundance of coral disease were analysed with XL-stat sotfware 2014 Principal Components Analysis method, where as the distribution of coral disease was analysed by using the Analysis Correspondent method. From the results, the type of interference is found in the observation location of Tunda Island Banten, such as coral bleaching (Full, Patches and Stripes), while other health disorders such as COTS, fishbite, PR, IG, SP and SD. Patches of coral bleaching form werea form of coral bleaching that are found on the entire location of the observations with the total colony that was attacked as many as 91 colonies. While health problems SP (Sponge Over) was a medical disorder bit (7 colonies) found in the observation location. The distribution of coral bleaching seems be linked to salinity, temperature and phosphate while coral health disorders $S D$ and SP have been associated with the concentration of nitrate and silicate.
\end{abstract}

Keywords:Coral diseases, abundance, Tunda Island

Hubungan Parameter Lingkungan Terhadap Gangguan Kesehatan Karang Di Pulau Tunda - Banten - Dedi, Neviaty P. Zamani, dan Taslim Arifin 


\section{PENDAHULUAN}

Pulau Tunda merupakan pulau kecil terluar yang terdapat didaerah Teluk Banten secara administrasi pulau ini berbatasan dengan pulaupulau kecil yang terdapat di Kawasan Teluk Jakarta Bagian timur. Pulau Tunda berbatasan dengan Gugusan Pulau Pari dan Pulau Tidung Kepulauan Seribu.Bagian Selatan berhadapan langsung dengan Teluk Banten dan daratan Pulau Jawa.Bagian Utara berbatasan dengan Laut Jawa.Perairan Pulau Tunda sangat dipengaruhi oleh aktifitas-aktifitas dari daratan yang berasal dari Teluk Banten dan Teluk Jakarta. Pengerukan pasir di wilayah utara Pulau Tunda dapat menyebabkan kestabilan ekosistem di pulau tersebut terganggu.Jarak pulau Tunda kurang lebih $28 \mathrm{~km}$ dari dari muara Teluk Banten sedangkan jarak Pulau Tunda dan Teluk Jakarta berkisar $70 \mathrm{~km}$.Pengaruh dari aktifitas pembangunan dan indurtri dari Teluk Jakarta dan Teluk Banten berdampak pada beberapa ekosistem bawah laut yang terdapat di kawasanpulau-pulau kecil yang berada diperairan sekitar.Kondisi terumbu karang Pulau Tunda dapat terancam dengan eksplorasi karang batu yang berlebihan untuk pembangunan pondasi pemukiman.Selain itu, faktor keberadaan penduduk yang menyebabkan terjadinya pembuangan limbah rumah tangga dapat menyebabkan tekanan terhadap lingkungan tersebut.Riska et al. (2015) melaporkan akumulasi logam berat diperairan pulau Tunda Banten mengalami peningkatan dilihat dari pita tahunan karang Porites lutea.Potensi akumulasi logam berat tersebut terjadi diakibatkan oleh berbagi sumber baik secara alami dan antopogenik dari daerah sekitar pulau Tunda.

Lalang et al. (2015) melaporkan pertumbuhan karang Porites lutea menjadi menurun ketika terjadi peningkatan suhu sebesar $29,57^{\circ} \mathrm{C}$. Furby et al.(2014) menyimpulkan bahwa peningkatan suhu muka air laut dapat meningkatkan patogen virus dan dapat menyebabkan ketahanan (kekebalan) organisme karang menjadi berkurang. Faktor lain yang dapat mempengaruhi kerusakan terumbu karang yaitu proses El-Ninoyang menyebabkan terjadinya pemutihan karang pada beberapa daerah di belahan dunia seperti di daerah Samudra Hindia dan Samudra Pasifik. Proses ElNinomenyebabkan kenaikan suhu permukaan air laut dapat mempengaruhi pertumbuhan karang jenis Porites lutea (Arman et al., 2013). Peningkatan suhu sebesar $29,57^{\circ} \mathrm{C}$ menyebabkan penurunan pertumbuhan karang Porites lutea pada PulauTunda Banten (Lalang et al., 2015).Faktor lingkungan dapat menyebabkan kerusakan terumbu karang (Le Tissier dan Bronw, 1996; Obura, 2009), beberapa faktor ekternal dapat menyebabkan kematian pada koloni karang (Douglas, 2003).Peningkatan kerusakan terumbu karang dapat disebabkan oleh beberapa hal, seperti peningkatan suhu (Kushmaro et al.,1998; Baird dan Marshall, 2002; Yeeet et al.,2011; McClanahan et al., 2003; Suharsono,1999; Petterson et al.,2002; Furby et al., 2014, Burke et al., 2004, Baker et al., 2008,), sedimentasi (Rogers 1990; Weberet al., 2012; Bartley et al.,2014; Adriman et al., 2013; Erftemeijer et al.,2012), predator (Rotjan dan Lewis, 2008; Zamani, 2015), pengayaan nutrien(Brown, 1997; Nordemar et al., 2003; Bell, 1992; Dunn et al., 2012),

Zamani (2015) menjelaskan bahwa kesehatan terumbu karang dapat dilihat dari kelimpahan predator dari jenis Acanthaster plancy (mahkota berduri). Kesehatan karang pada Tunda Banten belum ada yang melakukan pengamatan sebelumnya. Penelitian ini dilakukan untuk menjawab apakah parameter lingkungan memiliki hubungan dengan sebaran gangguan kesehatan karang.

\section{BAHAN DAN METODE}

\section{Waktu dan tempat Penelitian}

Penelitian inidilaksanakan pada Januari 2014. Pengamatan kondisi sebaran keragaman penyakit karang dilakukan pada pulau Tunda Banten (Gambar 1) 


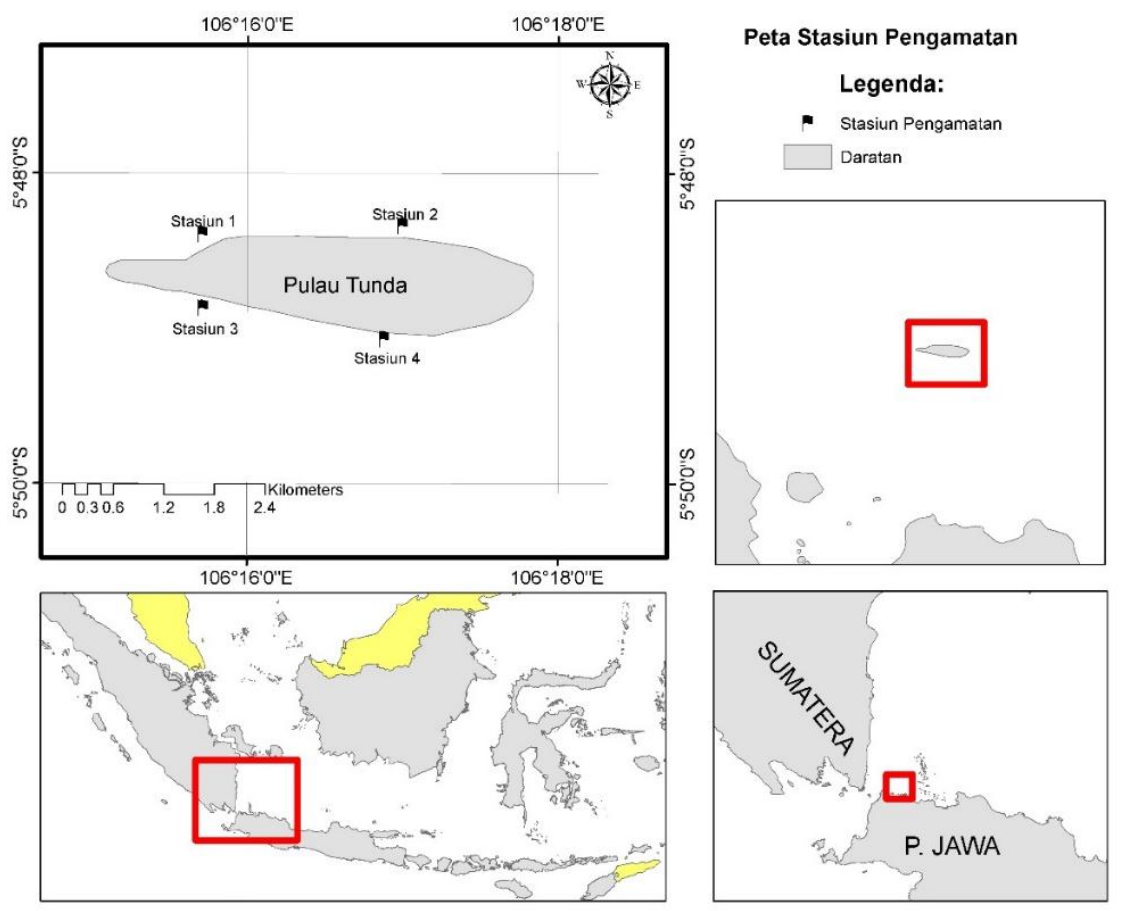

Gambar 1. Peta Lokasi pengamatan.

Figure 1.Map of Research Site.

\section{Pengumpulan data}

Data sebaran intensitas kesehatan karang diambil menggunakan metode transek sabuk(belt transect) dengan lebar transek 1 meter kiri dan 1 meter kanan dengan mengikuti garis transek sepanjang 50 meter. Jenis dan tingkat kesehatan karang diambil dan di identifikasi sesuai buku panduan penyakit karang menurut Beeden et al. (2008). Parameter fisika seperti arus, kecerahan, DO, salinitas, suhu dan $\mathrm{pH}$ diambil secara insitu dengan menggunakan TOA DKK, sedangkan parameter kimia perairan seperti nitrat, fosfat dan silikat dianalisis di Laboratorium Produktifitas Perariran IPB.

\section{Analisis data}

Kelimpahan kesehatan karang dilakukan perhitungan dengan melakukan perbandingan antara jumlah individu (koloni) yang terserang penyakit dibagi dengan luas area pengamatan.Untuk mengetahui sebaran intensitas kesehatan karang pada lokasi pengamatan dilakukan analisis statitika dengan menggunakan metode Correspondent Analysis(CA) dan hubungan parameter fisikokimiawi dengan sebaran intensitas kesehatan karang dianalisis dengan medote Principal Components Analysis (PCA) dengan software XLstat 2014.

\section{HASIL DAN PEMBAHASAN}

\section{Kelimpahan Intensitas Infeksi Gangguan Kesehatan Karang}

Dari hasil pengamatan yang dilakukan terdapat beberapa jenis gangguan kesehatan karang yang terdapat pada lokasi pengamatan. Jenis gangguan yang terdapat pada lokasi pengamatan Pulau Tunda Banten yaitu pemutihan karang (Full, Patches, dan Stripes) sedangkan gangguan kesehatan lainnya seperti (Cots, fishbite, PR, IG, SP dan SD). Pemutihan karang bentuk Patches merupakan bentuk pemutihan karang yang banyak ditemukan dari seluruh lokasi pengamatan dengan total koloni yang terserang sebanyak 91 koloni. Gangguan kesehatan SP (Spons Over) merupakan 
gangguan kesehatan yang sedikit (7 koloni) ditemukan pada lokasi pengamatan.Pemutihan karang terjadi akbit terjadinya perubahan suhu muka air laut yang menyebabkan hewan yang bersimbiosis dengan karang melepaskan diri dari koloni karang. Pemutihan karang pada lokasi pengamatan ditemukan beberapa bentuk seperti Full sebanyak 52 koloni dan Stripes 17 koloni.Ganguan kesehatan yang lain seperti
Cots (12 koloni), fishbite (23 koloni), PR (49 koloni), IG (38 koloni) dan SD (50 koloni). Intensitas kesehatan karang yang dominan pada daerah pulau Tunda merupakan gangguan kesehatan karang yang disebabkan oleh pengaruh lingkungan seperti Pemutihan karang (Full dan Patches) sedangkan gangguan kesehatan karang yang dominan yaitu fishbite, PR, IG dan SD(Tabel 1)

Tabel 1. Kelimpahan Pemutihan Karang dan Gangguan Kesehatan Karang Pulau Tunda Banten.

Table 1. Abundance Coral Bleaching and Compramission Health Tunda Island Banten.

\begin{tabular}{llcccc}
\hline \multicolumn{2}{c}{ Bentuk infeksi (gangguan) } & Stasiun 1 & Stasiun 2 & Stasiun 3 & Stasiun 4 \\
\hline \multirow{2}{*}{ Pemutihan } & Full & 12 & 4 & 20 & 16 \\
Karang & Patches & 10 & 12 & 28 & 41 \\
& Stripes & 2 & 0 & 11 & 4 \\
& Cots & 4 & 0 & 0 & 8 \\
Gangguan & Fisbite & 2 & 6 & 10 & 5 \\
Kesehatan & PR & 0 & 13 & 28 & 8 \\
& IG & 13 & 8 & 17 & 0 \\
& SP & 0 & 12 & 20 & 10 \\
\hline
\end{tabular}

Keterangan : Full : Putih seluruh, Patches : tambalan putih, Stripes: Garis Putih, COTS = Crown-of-Thorns Starfish, Fish = Fish bitePR = Pigmentation Respon, $\mathrm{IG}=$ Invertebrate Galls, $\mathrm{SP}=$ Spons Over, $\mathrm{SD}=$ Sedimentation Damage.

Gangguan kesehatan karang pada setiap stasiun pengamatan memiliki perbedaan (Gambar 2).Pada stasiun 1 IG (13 koloni) merupakan gangguan kesehatan yang paling banyak ditemukan, stasiun 2 PR (13 koloni), stasiun 3 PR (28 koloni) dan Pacthes (28 koloni) sedangkan pada stasiun 4 Pacthes (41 koloni) merupakan gangguan pemutihan karang yang paling banyak ditemukan.Sebaran intensitas kesehatan karang yang berbeda pada setiap lokasi pengamatan dipengaruhi oleh karakteristik perairan Pulau Tunda yang dipengaruhi oleh aktifitas masyarakat serta peningkatan suhu permukaan laut yang terjadi pada seluruh belahan bumi.

Pemutihan karang terjadi akibat hilangnya organisme karang (zooxanthella) yang keluar dari polip karang (Douglas, 2003). Pemutihan karang umumnya dikategorikan dalam jenis penyakit karang yang disebabkan oleh tekanan lingkungan seperti naiknya suhu permukaan laut (Yee et al., 2008; Glynn, 1993; Cervino et al.,2004; McClanahan, 2004), penuruan suhu laut (Coles dan Fadlallah,1991) dan peningkatan radiasi matahari (Le Tissier dan Bronw, 1996). Pemutihan karang merupakan reaksiterhadap perubahan lingkungan yang menyebabkan keluarnya polip karang ketika terjadinya stres pada karang (Hayes dan Goreau, 1992). Selain suhu yang dapat menyebabkan terjadinya pemutihan karang, salinitas merupakan salah satu faktor yang berdampak pada terjadinya pemutihan karang.

Pigmentaion respons juga merupakan penggagu kesehatan yang ditemukan pada setiap lokasi pengamatan. Pigmentation respons banyak ditemukan pada karang-karang massive dari genus Porites. Pemudaran warna (tissue discoloration) dengan munculnya warna merah mudah atau ungu pada permukaan karang tersebut menandakan kesehatan karang tersebut terganggu.Benzoni (2010) menjelaskan bahwa respons dari munculnya bintik-bintik warna merah mudaatau ungu merupakan pengaruh dari mekanisme stres karang yang disebabkan oleh larva Cirriped yang menempel pada permukaan karang hidup pada genus Porites.

Sedimentation damage juga merupakan gangguan kesehatan karang yang dijumpai pada setiap lokasi pengamatan, kondisi ini disebabkan oleh tingginya aktivitas pada daratan Jakarta yang membawa sedimentasi hingga ke perairan pulau kecil di sekitar Teluk Jakarta. Sedimentasi merupakan faktor penting dalam tingkat stres yang terjadi pada karang. Beberapa 
spesies karang mengalami degradasi oleh tingginya tingkat sedimentasi di satu perairan.Gleason (1998) menjelaskan karang jenis P.astreoidesmampu mentoleransi tingkat sedimen yang tinggi. Rogers (1990) melaporkan peningkatan sedimentasi menyebabkan

\section{Stasiun 1}

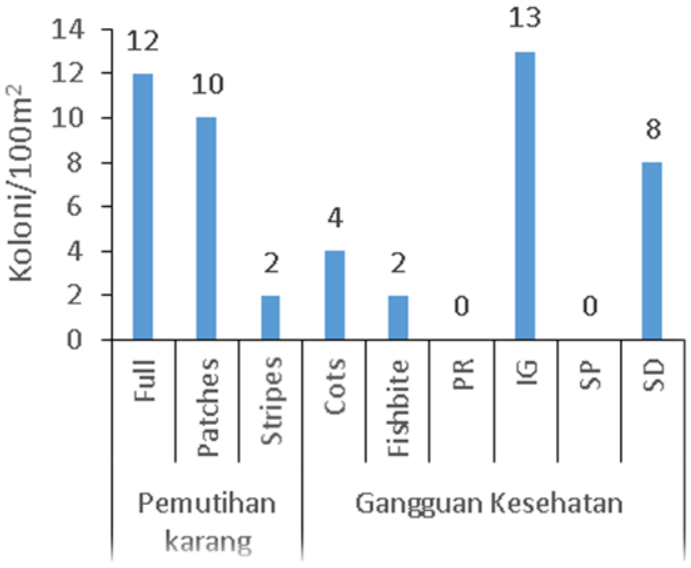

Stasiun 3

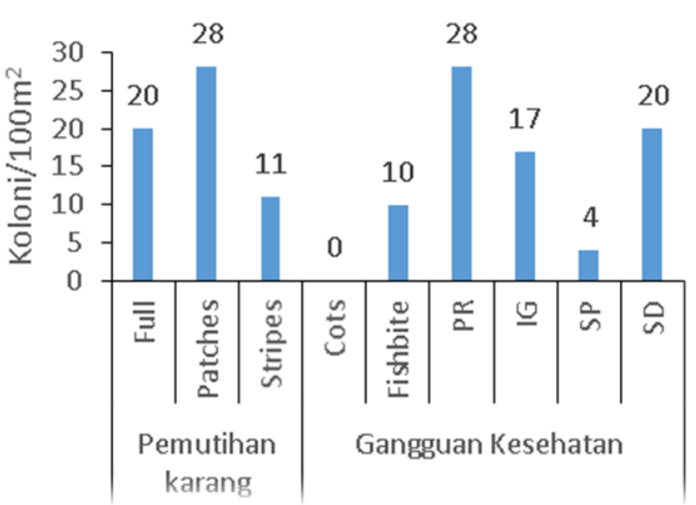

degradasi terumbu karang pada satu wilayah, partikel sedimen yang menutupi organisme karang dan mengurangi cahaya yang dibutuhkan untuk proses fotosintesis. Sedimentasi yang berlebihan dapat mengubah struktur komunitas karang baik secara fisik maupun secara biologis.

Gambar 2.Kelimpahan pemutihan karang dan gangguan kesehatan karang.

Figure 2. Abundance Coral Bleaching and Compramission Health.

Genus Acropora dan Porites ditemukan paling dominan pada setiap lokasi pengamatan (Gambar 3), hal ini dikarenakan genus karang Porites dan Acropora merupakan genus karang yang paling banyak terdapat pada lokasi pengamatan. Menurut Edinger (2000), terumbu karang didaerah dekat pantai yang memiliki tingkat pencemaran yang tinggi akan didominasi oleh terumbu karang sub massive dan karang massive. Beberapa karang sub massive dan karang massive merupakan genus Porites yang banyak terdapat pada daerah pengamatan.
Myers dan Raymundo (2009) menjelaskan genus karang Acropora dan Porites yang rentan terhadap beberapa penyakit yang timbul pada suatu perairan. Roff et al. (2006) menjelaskan karang Acropora spp pada daerah Great Barrier Reef paling banyak ditemukan terserang penyakit White syndrom yang menyerang bagian lesi karang. Rogers et al. (2005) menerangkan dibeberapa terumbu karang Florida terjadi penyebaran penyakit karang white pox disease (penyakit cacar putih) pada jenis karang Acropora palmata. 
Stasiun 1

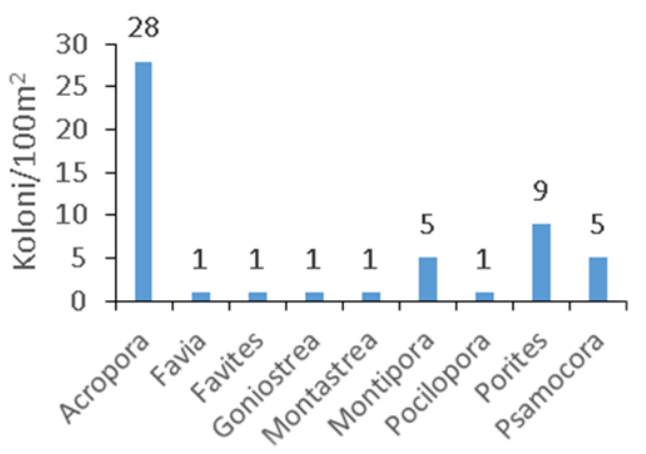

Stasiun 3

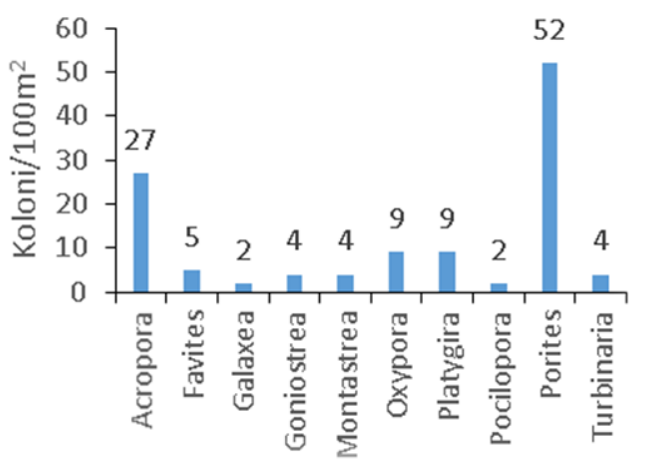

Stasiun 2

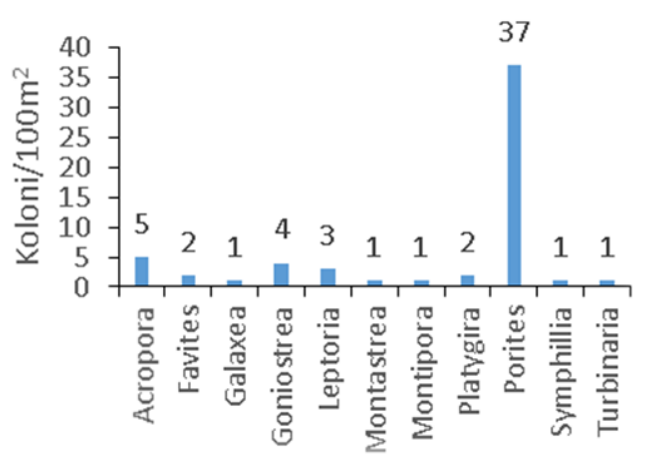

Stasiun 4

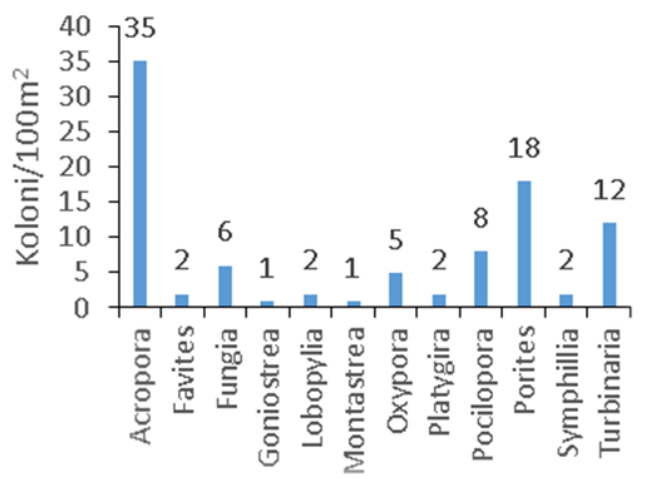

Gambar 3.Kelimpahan Genus yang terinfeksi pemutihan karang dan gangguan kesehatan karang. Figure 3. Abundance Coral Bleaching and Compramission Health to infention of Genus.

Thurber et al. (2008) menjelaskan karang jenis Porites compressa mengandung virus eukariotik, virus tersebut akan merespon tanggapan stres pada karang yang disebabkan oleh penurunan $\mathrm{pH}$, peningkatan nutrisi, dan stres termal yang terjadi pada koloni karang. Pemanasan global memberikan dampak negatif pada kesehatan karang. Nordemar et al. (2003) melaporkan respon fisiologis karang jenis Porites clyndirica yang terkena pengayaan anorganik terlarut dan peningkat suhu lebih dari $2^{\circ}$ C. Pengayaan nitrat yang signifikan mengurangi tingkat produksi primer dan menurunkan konsentrasi klorofil pada koloni Porites clyndrica. Peningkatan suhu permukaan menyebabkan kerusakan pada jaringan karang yang menimbulkan pemutihan pada bagianbagian terentu atau seluruhnya pada koloni tersebut. Tingkat kematian dan kerusakan karang juga dapat disebabkan oleh dampak lingkungan yang tinggi. Faktor lain yang dapat mempengaruhi kerusakan terumbu karang yaitu proses El-Ninoyang menyebabkan terjadinya pemutihan karang pada beberapa daerah di belahan dunia seperti di daerah Smaudra Hindia dan Samudra Pasifik. Proses ElNinomenyebabkan Kenaikan suhu permukaan air laut dapat mempengaruhi pertumbuhan karang jenis Porites lutea (Arman et al.,2013). Peningkatan suhu sebesar $29,57^{\circ} \mathrm{C}$ menyebabkan penurunan pertumbuhan karang Porites lutea pada pulauTunda Banten (Lalang et al., 2015).

\section{Parameter Lingkungan}

Beberapa parameter lingkungan diambil secara insitu pada lokasi pengamatan sedangkan parameter lingkungan seperti nitrat, fosfat, dan silikat dianalisis di Laboratorium Produktifitas Lingkungan (Prolink) IPB. Dari hasil pengamatan (Tabel 2), didapatkan beberapa parameter lingkungan yang diambil untuk mengetahui hubungan terhadap kondisi terumbu karang pada Pulau Tunda Banten. Hasil yang didapatkan dari pengamatan secara insitumenunjukkanbahwa nilaisalinitas, suhu, 
$\mathrm{pH}$, oksigen terlarut (DO) dan arusberkisar berturut turut antara30-32 psu, $29-32{ }^{\circ} \mathrm{C}, 8,1-$ $8,3, \quad 6,8-7,7 \quad \mathrm{mg} / \mathrm{l} \quad$ dan0,050-0,019 $\mathrm{m} /$ detik.Konsentrasi nutrien yang meliputinitrat,fosfat dan silikatberkisar antara0,007 - 0,052 mg/liter, 0,014 -0,040 $\mathrm{mg} / \mathrm{liter}$ dan $0,008-0,011 \mathrm{mg} / \mathrm{liter}$.

Tabel 2. Kondisi Parameter Fisik dan Kimia Pulau Tunda

Table 2. Condition Physical and Chemical Parameters of Tunda Island

\begin{tabular}{lcccc}
\hline \multicolumn{1}{c}{ Parameter lingkungan } & Stasiun 1 & Stasiun 2 & Stasiun 3 & Stasiun 4 \\
\hline Salinitas (psu) & 30 & 31 & 31 & 32 \\
Suhu $\left({ }^{\circ} \mathrm{C}\right)$ & 29 & 32 & 30 & 30 \\
$\mathrm{pH}$ & 8,2 & 8,1 & 8,3 & 8,3 \\
DO $(\mathrm{mg} / \mathrm{l})$ & 7,7 & 7,1 & 6,9 & 6,8 \\
Arus $(\mathrm{m} / \mathrm{detik})$ & 0,06 & 0,19 & 0,12 & 0,05 \\
Nitrat $(\mathrm{mg} / \mathrm{l})$ & 0,007 & 0,052 & 0,014 & 0,040 \\
Fosfat $(\mathrm{mg} / \mathrm{l})$ & 0,020 & 0,026 & 0,014 & 0,040 \\
Silikat(mg/l) & 0,009 & 0,011 & 0,008 & 0,010 \\
\hline
\end{tabular}

\section{Sebaran Gangguan Kesehatan Karang Berdasarkan Karakteristik Habitat}

Dari hasil analisi PCA terdapat 2 sumbu (F1 dan F2) dengan kontribusi masing-masing sumbu sebesar 55,41\% untuk sumbu (F1) dan 27,24\% untuk sumbu (F2) dari ragam total sebesar $82,64 \%$. Sumbu I dicirikan dengan enam variable utama yaitu salinitas $(0,621)$, fosfat $(0,836)$, suhu $(0,884)$, nitrat $(0,925)$, arus $(0,715)$, dan silikat $(0,692)$, sedangkan pada sumbu II dicirikan oleh $\mathrm{pH}(0,707)$ dan DO $(0,835)$. Gambar 4 menunjukkan bahwa pada lokasi pengamatan memiliki kecenderungan dengan karakteristik yang berbeda terlihat dari pengelompokan habitat berdasarkan parameter lingkungan di perairan tersebut. Beberapa parameter lingkungan menyebabkan terjadi pengelompokkan pada lokasi pengamatan. Terdapat empat kelompok (Gambar 4) pada grafik hasil analisis PCA kelompok I (Stasiun 2) dicirikan oleh salinitas, suhu, fosfat, nitrat, silikat dan arus. Kelompok II (Stasiun 3 dan 4) dicirikan dengan nilai $\mathrm{pH}$ (derajat keasaman air). Kelompok III (Stasiun 1) dicirikan nilai DO (oksigen terlarut).

Kelompok I (Stasiun 2) dicirikan oleh salinitas, suhu, fosfat, nitrat, silikat dan arus. Perubahan salinitas menyebabkan kerusakan sel-sel penting yang berkembang secara fisiologis dari sistem perkembangan organisme karang. Tekanan stres karang terhadap pengaruh salinitas tidak menunjukkan perubahan yang signifikan tetapi pengaruh salinitas dapat menyebabkan beberapa spesies karang tertentu dapat mentoleransi perubahan salinitas perairan. Menurut Seveso et al. (2013), fragmenS. caliendrum dapat merespon perubahan salinitas pada kondisi hypersaline dan hyposaline sekalipun.Perubahan salinitas yang drastis dapat menyebabkan terjadinya pemutihan karang.Fluktuasi salinitas dapat disebabkan oleh beberapa faktor alam seperti curah hujan, asupan air tawar dari daratan dan penyinaran matahari. Menurut Snedaker (1995), kenaikan muka air laut dapat disebabkan oleh meningkatnya salinitas yang berakibat pada peningkatan sulfida dalam sedimen. Perubahan salinitas mempengaruhi ekspresi Hsp60 yang dapat menyebabkan stres yang terjadi pada karang jenis $S$. caliendrum. Penurunan dan peningkatan salinitas sangat dipengaruhi oleh kondisi curah hujan di suatu daerah. Penurunan salinitas 2225psu menyebabkan stres pada karang yang sensitif. 



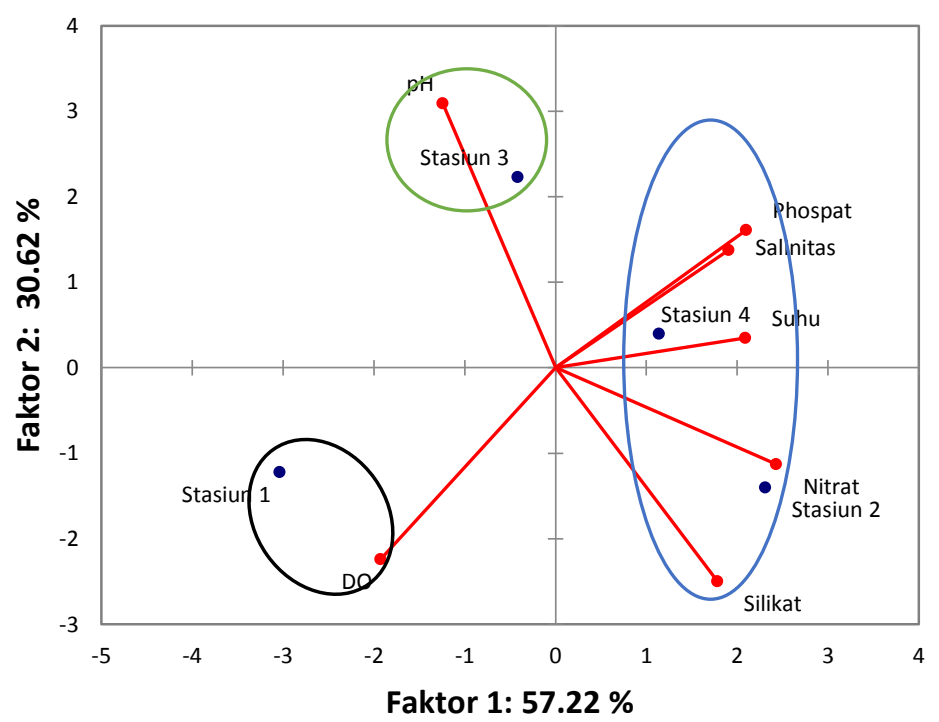

Gambar 4. Analisis komponen utama berdasarkan karakteristik habitat.

Figure 4. Principal component analysis on the characteristic habitat.

Kelompok II (Stasiun 3 dan 4) dicirikan dengan nilai $\mathrm{pH}$ (derajat keasaman air). Derajat keasaman $(\mathrm{pH})$ memiliki korelasi negatif dengan silikat $(-0,949)$ dan nitrat $(-0,729)$,pHperairan dapat berakibat pada kerusakan organisme karang. Nilai $\mathrm{pH}$ pada perairan Pulau Tunda berkisar antara 8,1-8,3. Kisaran $\mathrm{pH}$ yang didapatkan pada saat pengamatan masih dalam kategori yang cocok untuk pertumbuhan karang. Menurut Tomascik et al. (1997), habitat yang cocok untuk pertumbuhan karang dengan kisaran $\mathrm{pH}$ 8,2-8,5, tetapi nilai $\mathrm{pH}$ yang berkorelasi negatifterhadap nitrat dan fosfat menyebabkan konstrasi nitrat dan fosfat meningkat. Peningkatan konstrasi nitrat dan fosfat dapat disebabkan oleh limbah buangan yang terdapat pada daerah sekitar pulau atau masukan dari Teluk Banten yang terbawa oleh arus perairan.Tingkat antropogenik dapat menyebabkan peningkatan nutrisi diperairan yang berakibat pada perubahan kualitas air di daerah ekosistem terumbu karang. Kombinasi suhu dan nitrat yang tinggi menyebabkan penurunan kepadatan zooxanthella dan mengurangi tingkat produksi primer organisme karang (Nordemar et al.,2003). Dunn et al. (2012) menyebutkan kontaminasi fosfat dapat mempengaruhi organisme karang, mengubah tingkat petumbuhan, reproduksi karang, kematian karang dan kepadatan zooxanthella. Konsentrasi silikat yang tinggi dapat menentukan tinggi rendahnya kelimpahan fitoplankton pada suatu perairan. Menurut Pangaribuan et al. (2013), konsentrasi kandungan fosfat dan nitrat disuatu perairan sangat menentukan tinggi rendahnya densitas zooxanthella yang terdapat pada koloni karang jenis Acropora sp. Pengayaan nutrisi dapat menyebabkan terjadinya penyakit band kuning pada jenis Montastraea annularis dan Montastrae franksii (Bruno et al., 2003).

Suhu merupakan salah satu faktor yang banyak menyebabkan terjadinya kerusakan karang khususnya yang menyebabkan terjadinya pemutihan karang di berbagai perairan termasuk di Indonesia. Peningkatan dan penurunan suhu dapat berakibat terjadinya stres pada karang.Kisaran suhu pada lokasi pengamatan 28-32 ${ }^{\circ} \mathrm{C}$. Peningkatan suhu $0,5^{\circ} \mathrm{C}$ di daerah subtropis dapat menyebabkan pemutihan karang dan mengeluarkan simbiosis alga yang terdapat pada koloni karang (Wilkinson, 2008).Baker et al. (2008) melaporkan pemutihan karang terjadi selama Agustus hingga Oktober di daerah Karibia yang diakibatkan oleh anomali permukaan laut terjadi pada 1983-2000. Pemutihan karang dapat terjadi karena suhu 
rata-rata permukaan laut meningkat lebih dari $30^{\circ} \mathrm{C}$ (Burke et al., 2004).Nordemar et al. (2003) melaporkan peningkatan suhu lebih dari $2^{\circ} \mathrm{C}$ dapat mengurangi tingkat produktifitas primer karang Porites clyndrica. Peningktan suhu permukaan air laut terjadi dikarenakan proses El-Nino. Arman et al. (2013) menjelaskan pertumbuhan karang jenis Porites lutea dipengaruhi oleh terjadinya proses $E l$ Ninoyangmenyebabkan terjadinya kenaikan suhu muka air laut. Lalang et al. (2015) melaporkan pertumbuhan karang Porites lutea menjadi menurun ketika terjadi peningkatan suhu sebesar $29,57^{\circ} \mathrm{C}$. Peningkatan suhu muka air laut dapat meningkatkan patogen virus dan dapat menyebabkan ketahanan (kekebalan) organisme karang menjadi berkurang (Furby et al.,2014).

Kelompok III (Stasiun 1) dicirikan olehnilai DO (oksigen terlarut). Kisarannilai DO adalah 6,87,7 mg/l. Menurut KEPMEN LH (2004), standar baku mutu air laut untuk biota perairan untuk DO dengan kisaran $>5 \mathrm{mg} / \mathrm{l}$ untuk kehidupan organisme laut, sedangkan nilai DO pada lokasi pengamatan 6,8-7,7 mg/l memperlihatkan masih dalam ketegori sesuai untuk kehidupan biota laut.

Tabel 3.Korelasi antar Variabel

Table 3. Correlation among variables

\begin{tabular}{lrrrrrrr}
\hline \multicolumn{1}{c}{ Variables } & \multicolumn{1}{c}{ Salinitas } & \multicolumn{1}{c}{ Suhu } & \multicolumn{1}{c}{$\mathrm{pH}$} & Nitrat & Fosfat & Silikat & DO \\
\hline Salinitas & $\mathbf{1}$ & & & & & & \\
Suhu & 0,316 & $\mathbf{1}$ & & & & & \\
$\mathrm{pH}$ & 0,000 & $-0,316$ & $\mathbf{1}$ & & & & \\
Nitrat & 0,634 & 0,662 & $-0,729$ & $\mathbf{1}$ & & & \\
Fosfat & 0,577 & 0,913 & 0,000 & 0,576 & $\mathbf{1}$ & & \\
Silikat & 0,316 & 0,400 & $-0,949$ & 0,892 & 0,183 & $\mathbf{1}$ & \\
DO & $-0,911$ & $-0,544$ & $-0,203$ & $-0,522$ & $-0,819$ & $-0,096$ & $\mathbf{1}$ \\
\hline
\end{tabular}

Berdasarkan analisis CA (Corresponden Analysis) terdapat tiga karakteristik habitat yang mencirikan tingkat kemunculan infeksi kesehatan karang pada lokasi pengamatan. Kelompok I (Stasiun 2 dan Stasiun3) dicirikan dengan banyaknya ditemukan jenis gangguan kesehatan seperti SP, PR, Fishbite, Stripes, dan SD. Kelompok ini dicirikan dengan nilai $\mathrm{pH}$, nitrat dan silikat yang tinggi pada lokasi pengamatan tersebut (Gambar 8).Fisbite merupakan bentuk dari gigitan-gigitan ikan pemakan karang yang berasosiasi dan memanfaatkan karang sebagai makanan. Ikan pemakan karang dari Family ikan Chaetodontidae merupakan salah satu pemangsa terbesar koloni karang. Ikan Chaetodontidae memakan polip karang pada beberapa genus karang seperti Porites, Acropora, Agaricites, Pocillopora, dan Montipora (Rotjan dan Lewis, 2008).
Peningkatan dan penurunan konsentrasi nutrien (nitrat, fosfat dan silikat) dapat menyebabkan terjadinya pemutihan karang dan kematian secara spasial di beberapa karang tepi (Kuntz et al.,2005). Pengayaan nutrien pada suatu perairan tergantung pada tinggi rendahnya konsentrasi nitrat dan fosfat yang terdapat diperairan tersebut. Kisaran konsentrasinitrat yang baik untuk kesehatan karang yaitu 0,040 $\mathrm{mg} / \mathrm{l}$ sedangkan untuk kisaran fosfat $0,07 \mathrm{mg} / \mathrm{l}$ (Bell, 1992). Nilai konsentrasi dari hasil analisis, kisaran nitrat 0,07-0,124 mg/l. Nilai kadar fosfat yang terdapat pada lokasi penelitian berkisar $0,04-0,028 \mathrm{mg} / \mathrm{l}$. Nilai konsentrasi kadar nitrat dan fosfat dilokasi penelitian telah melebihi kisaran untuk kesehatan karang di suatu perairan. Menurut Dunn et al. (2012), kontaminasi konsentrasi fosfat yang berlebihan dapat mempengaruhi organisme karang. 


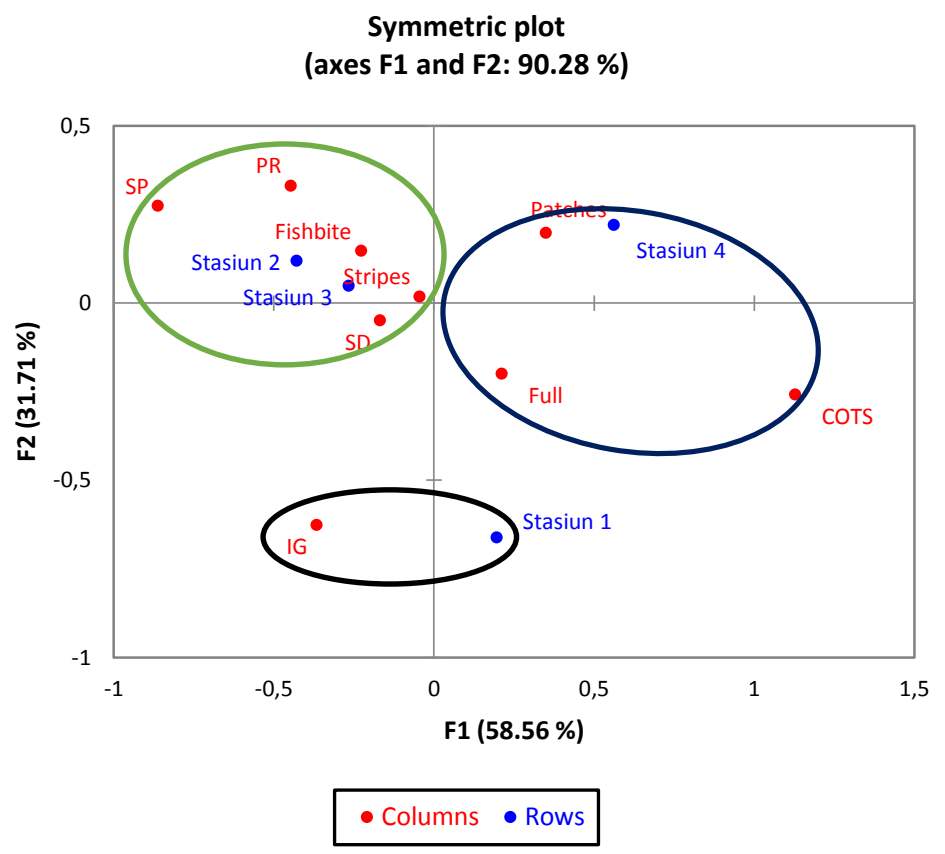

Gambar 5. Sebaran keseragaman infeksi kesehatan karang berdasarkan analisis koresponden.

Figure 5. Distribution of uniformity in infection coral health on the correspondent analysis.

Peningkan nutrien perairan disebabkan oleh tingginya sedimentasi yang terdapat diperairan tersebut. Peningkatan sedimentasi dapat menyebabkan munculnya beberapa gangguan kesehatan karang seperti SP dan SD. Pada beberapa jenis karang terdapat gangguan kesehatan karang baik itu SP maupun SD yang terdapat pada lokasi pengamatan. Sebaran SP dan SD yang terdapat pada lokasi pengamatan terjadi akibat tingginya sedimentasi di lokasi pengamatan dan adanya kompetisi antara komutitas spons dan karang. Spons over (SP) menunjukkan adanya kompetisi antara terumbu karang dan biota asosiasi spons yang berada diperairan tersebut. Tingginya invasif spons disebabkan oleh kandungan nutrien perairan tersebut meningkat. Menurut Ward-Paige et al. (2005) penurunan tutupan karang dan dapat disebabkan oleh peningkatan kelimpahan spons dengn meningkatnya nutrisi suatu perairan. Sabine et al. (2015) menyebutkan faktor alam dan tingkat antropogenik dapat mempengaruhi kemampuan karang untuk pulih dari penyembuhan infeksi jaringan (lesi) dan mengganggu regenerasi larva karang. Kompetisi ruangan pada terumbu karang juga dapat disebabkan oleh munculnya komunitas alga. Kerusakan jaringan karang dapat terjadi disebabkan oleh munculnya komunitas alga merah seperti Corallophila huysmansi yang dapat membunuh jaringan karang (Jompa dan McCook, 2003).

Kelompok II (Stasiun4) dicirikan dengan sebaran Patches, Full dan COTS. Stasiun 4 merupakan lokasi pengamatan pada daerah yang berdekatan dengan aktivitas manusia.Kelompok ini dicirikan oleh sebaran salinitas, suhu dan fosfat yang tinggi.Pengaruh salinitas dapat memberikan dampak pada pertumbuhan karang dan dapat menyebabkan terjadinya pemutihan karang pada daerah dengan salinitas yang tinggi. Dikawasan Pulau Tunda banyak ditemukan kondisi karang yang telah terjadi pemutihan. Peningkatan suhu mempengaruhi kepadatan zooxanthella dengan penurunan hingga $21-61 \%$, sedangkan konsentrasi nutrien tidak memberikan dampak pada pemutihan karang (Tanaka et al., 2014). Konsentrasi fosfat diperairan Pulau Tunda telah melewati baku mutu biota laut $(0,015 \mathrm{mg} / \mathrm{l})$, sedangkan nilai konsentrasi fosfat pada lokasi pengamatan berkisar 0,014-0,040 mg/l (Tabel 1). Pada kelompok ini, hasil dari analisis CA memberikan informasi bahwa sebaran pemutihan karang dalam bentuk Patches lebih besar dibandingkan yang lain, sedangkan sebaran COTS disebabkan oleh terdapatnya biota pemangsa koloni karang seperti mahkota berduri yang mengakibatkan hilangnya jaringan 
karang dan menyebabkan terjadinya pemutihan karang. Zamani (2015) menjelaskan bahwa kesehatan terumbu karang dapat dilihat dari kelimpahan predator dari jenis Acanthaster plancy (mahkota berduri). Beberapa predator seperti ikan, mahkota berduri dan biota asosiasi lainnya dapat menyebabkan kehilangan jaringan karang. Works dan Aeby (2011) menjelaskan predator seperti Drupella $s p$ dan mahkota berduri (Acanthaster planci) dapat menyebabkan kehilangan jaringan karang.

Kelompok III (Stasiun1) dicirikan dengan IG (Invetebrate galls), merupakan kelompok dengan sebaran gangguan karang seperti (Invetebrate galls) yang relatif lebih besar dibandingkan dengan lokasi lainnya, sedangkan bila dilihat pada grafik PCA (Gambar 8).Kelompok ini dipengaruhi oleh nilai DO (derajat keasaman) perairan. Invetebrate galls dan Druppella merupakan biota-biota asosiasi yang terdapat pada terumbu karang yang mendiami baik didalam koloni karang maupun di sekitar wilayah kehidupan karang. Sebagian besar merupakan jenis-jenis dari kerangkerangan dan siput yang menempel pada karang. Menurut Glynn dan Enochs (2011), beberapa spesies invetebrata yang berasosiasi dengan terumbu karang memberikan dampak pada kerusakan struktur komunitas karang ataupun pada kelimpahan jenis karang.

\section{KESIMPULAN DAN SARAN}

Gangguan kesehatan karang yang ditemukan yaitu pemutihan karang (Full, Patches, dan Stripes), sedangkan gangguan kesehatan lainnya meliputi Cots, fishbite, PR, IG, SP dan SD.Sebaran intensitas kesehatan karang dipengaruhi oleh parameter lingkungan perairan.Sebaran pemutihan karang memiliki hubungan terhadap salinitas, suhu dan fosfat, sedangkan gangguan kesehatan karang SD dan SP memiliki hubungan terhadap konsentrasi nitrat dan silikat.

\section{UCAPAN TERIMAKASIH}

Penelitian ini didanai dari Anggaran DIPA Puslitbang Sumberdaya Laut dan Pesisir, Badan Liitbang Kelautan dan Perikanan, Kementerian Kelautan dan Perikanan Tahun 2014. Ucapan terima kasih kepada (1) Kepala Pusat Penelitian dan Pengembangan Sumberdaya Laut dan Pesisir, atas izin dalam penentuan lokasi riset Teluk Jakarta 2014; Prof. Dr. Dedi Shoedharma atas saran dan masukannya dalam paper ini, dan (3) Kepada tim survey kegiatan riset pembangunan Giant Sea Wall2014 yang telah membantu di lapangan.

\section{DAFTAR PUSTAKA}

[KEPMEN LH] Keputusan Menteri Lingkungan Hidup Nomor 51. 2004.Baku Mutu Air Laut Untuk Biota Laut.

Adriman., A. Purbayanto, S. Budiharso, A. Damar. 2013. Pengaruh Sedimentasi Terhadap Terumbu Karang Di Kawasan Konservasi Laut Daerah Bintan Timur Kepulauan Riau. Jurnal Terubuk. 41(1): 90-101.

Arman A.A., N.P. Zamani, T.W. Watanabe. 2013. Studi Penentuan Umur dan Laju Pertumbuhan Terumbu Karang terkait dengan Perubahan Iklim Ekstrim Menggunakan Sinar-X. Jurnal Aplikasi Isotop Radiasi. 9(1): 1-10.

Baird A.H., P.A. Marshall. 2002. Mortality, growth and reproduction in scleractinian corals following bleaching on the Great Barrier Reef. J. Marine Ecology Progress Series. 237: 133141.doi:10.3354/meps237133.

Baker A.C., P.W. Glynn, B. Riegl. 2008. Climate change and coral reef bleaching: An ecological assessment of long-term impacts, recovery trends and future outlook. Estuarine, Coastal and Shelf Science. 80(4): 435471.doi:10.1016/j.ecss.2008.09.003.

Bartley R., Z.T. Bainbridge, S.E. Lewis, F.J. Kroon, S.N. Wilkinson, J.E. Brodie, D.M. Silburn. 2014. Relating sediment impacts on coral reefs to watershed sources, processes and management: A review. J. Science of the Total Environment. 468-469:11381153.doi:10.1016/j.scitotenv.2013.09.0 30.

Beeden R., B.L. Willis, L. Raymundo, C.A. Page, E. Weil. 2008. Underwater cards for assessing coral health on IndoPacific reefs. Coral Reef Targeted Research and Capacity Building for 
Management Program. Currie Communications, Melbourne, 22p.

Bell P.R.F. 1992.Eutrophication and coral reefs - some examples in the Great Barrier Reef Lagoon.Water Resources.5:553568.doi:10.1016/0043-1354 (92)90228$\mathrm{V}$.

Benzoni F., P. Galli, M. Pichon. 2010. Pink spots on Porites: not always a coral disease. J. Coral reefs. 29(1):153153.doi:10.1007/s00338-009-0571-z.

Brown B.E. 1997. Disturbances to Reefs in Recent Times.In.Life and Death of Coral. 354-379.

Bruno J.F., L.E. Petes, C. Drew Harvell, A. Hettinger. 2003. Nutrient enrichment can increase the severity of coral diseases. Ecology Letters. 6(12): 10561061.doi:10.1046/j.14610248.2003.00544.x.

Burke C.D., T.M. McHenry, W.D. Bischoff, E.S. Huttig, W. Yang, L. Thorndyke. 2004. Coral mortality, recovery and reef degradation at Mexico Rocks Patch Reef Complex, Northern Belize, Central America: 1995-1997. In Coelenterate Biology 2003 (pp. 481-487).Springer Netherlands.

Cervino J.M., R. Hayes, T.J. Goreau, G.W. Smith. 2004. Zooxanthellae regulation in yellow blotch/band and other coral diseases contrasted with temperature related bleaching: In situ destruction vs expulsion. J. Symbiosis. 37(1/3): 63-86.

Coles S.L., Y.H. Fadlallah. 1991. Reef coral survival and mortality at low temperatures in the Arabian Gulf: new species-specific lower temperature limits. J. Coral Reefs. 9(4):231237.doi:10.1007/BF00290427.

DouglasA.E.2003. Coral bleaching-how and why?.Marine Pollution Bulletin. 46(4), 385-392.doi:10.1016/S0025$326 x(03) 00037-7$.

Dunn J.G., P.W. Sammarco, G. LaFleur. 2012. Effects of phosphate on growth and skeletal density in the scleractinian coral Acropora muricata: A controlled experimental approach. Journal of Experimental Marine Biology and Ecology. 411: 34-44. doi:10.1016/j.jembe.2011.10.013.
Edinger E.N., M.J. Risk. 2000. Reef classification by coral morphology predicts coral reef conservation value. Biological Conservation. 92(1):1-13.

Erftemeijer P.L., B. Riegl, B.W. Hoeksema, P.A. Todd. 2012. Environmental impacts of dredging and other sediment disturbances on corals: a review. $J$. Marine Pollution Bulletin. 64(9):17371765.doi:10.1016/j.marpolbul.2012.05. 008.

Furby K.A., A. Apprill, J.M. Cervino, J.E. Ossolinski, K.A. Hughen. 2014. Incidence of lesions on Fungiidae corals in the eastern Red Sea is related to water temperature and coastal pollution. Marine Environmental Research. 98: 29-

38.doi:10.1016/j.marenvres.2014.04.00 2.

Gleason D.F. 1998. Sedimentation and distributions of green and brown morphs of the Caribbean coral Porites astreoides Lamarck.J.of Experimental Marine Biology and Ecology. 230(1):73-89.doi:s00220981(98)00084-7.

Glynn P.W. 1993. Coral reef bleaching: ecological perspectives. J. Coral Reefs. 12(1):1-17.doi: 10.1007/BF00303779.

Glynn P.W., I.C. Enochs. 2011. Invertebrates and their roles in coral reef ecosystems. In Coral reefs: an ecosystem in transition. 273-325pp. Springer Netherlands.doi: 10.1007/978-94-0070114-4_18

Hayes R.I., T.J. Goreau. 1992. Histology of Caribbean and south Pacific bleached corals. Proc. 7th Int. Coral Reef Symp.1:71pp.

Jompa J., L.J. McCook. 2003. Coral-algal competition: macroalgae with different properties have different effects on corals. Marine Ecology Progress Series. 258: 87-95.

Kuntz N.M., D.I. Kline, S.A. Sandin, F. Rohwer. 2005. Pathologies and mortality rates caused by organic carbon and nutrient stressors in three Caribbean coral species. Marine Ecology Progress Series. 294:173-180.

Kushmaro A., E. Rosenberg, M. Fine, Y.B. Haim,Y. Loya. 1998. Effect of 
temperature on bleaching of the coral Oculina patagonica by Vibrio AK- 1 . Marine Ecology Progress Series. 171:131-137.

Lalang. 2015. Laju Pertumbukah Linier Karang Porites lutea Menggunakan Sinar - X di Pulau Tunda Kebupaten Serang Provinsi Banten[Tesis]. Bogor (ID):Institut Pertanian Bogor.

Le Tissier M.D.A.A.,B.E. Brown. 1996. Dynamics of solar bleaching in the intertidal reefs coral Goniastrea aspera at KO Phuket, Thailand. Marine Ecology Progress Series. 136:235-244.

McClanahan T.R. 2004.The relationship between bleaching and mortality of common corals.Journal Marine Biology. 144(6):1239-1245.doi: 10.1007/s00227-003-1271-9.

McClanahan T.R., E. Sala, P.A. Stickels, B.A. Cokos, A.C. Baker, C.J. Starger, S.H. Jones. 2003. Interaction between nutrients and herbivory in controlling algal communities and coral condition on Glover's Reef, Belize. Marine Ecology Progress Series. 261:135-147.

Myers R.L., L.J. Raymundo. 2009. Coral disease in Micronesian reefs: a link between disease prevalence and host abundance. Diseases of Aquatic Organisms. 87(12): 97-104. doi: 0.3354/dao02139.

Nordemar I., M. Nystrom, R. Dizon. 2003. Effects of elevated seawater temperature and nitrate enrichment on the branching coral Porites cylindrica in the absence of particulate food. Marine Biology. 142(4): 669-677.doi: 10.1007/s00227-002-0989-0.

Obura D.O. 2009. Reefcoral bleach to resist stress. Marine Pollution Bulletin. 58:206-

212.doi:10.1016/j.marpolbul.2008.10.0 02.

Pangaribuan T.H., C. Ain, P. Soedarsono. 2013.Hubungan kandungan Nitrat dan Fospat dengan densitas zooxanthella pda polip karang Acropora sp di perairan terumbu karang menjangan kecil, Karimun Jawa. Managent of Aquatic Resources: 2(4): 136-145.

Patterson K.L., J.W. Porter, K.B. Ritchie, S.W. Polson, E. Mueller, E.C. Peters, G.W. Smith. 2002. The etiology of white pox, a lethal disease of the Caribbean Elkhorn coral, Acropora palmata. Proceedings of the National Academy of Sciences.PNAS. 99(13): 87258730.doi: 10.1073/pnas.092260099.

Riska. N.P. ZamanI, T. Prartono, A. Arman. 2015. Plumbum $(\mathrm{Pb})$ Concentration In Annual Bands Of Coral Porites Lutea At Tunda Island, Banten. Jurnal Ilmu dan Teknologi Kelautan Tropis, 7(1):235245

RoffG., O. Hoegh-Guldberg, M. Fine. 2006. Intra-colonial response to Acroporid "white syndrome" lesions in tabular Acropora spp.(Scleractinia). Coral Reefs, 25(2):255264.doi:10.1007/s00338-006-0099-4.

Rogers C.S. 1990.Responses of coral reefs and reef organisms to sedimentation.J.Marine Ecology Progress Series. 62(1):185-202.

Rogers C.S., K.P. Sutherland, J.W. Porter. 2005. Has white pox disease been affecting Acropora palmata for over 30 years?.Coral Reefs. 24(2): 194-194.doi: 10.1007/s00338-004-0470-2.

RotjanR.D., S.M.Lewis. 2008. Impact of coral predators on tropical reefs. Marine Ecology Progress Series. 367:7391.doi:10.3354/meps07531.

Sabine A.M., T.B. Smith, D.E. Williams, and M.E. Brandt. 2015. Environmental conditions influence tissue regeneration rates in scleractinian corals. Marine Pollution Bulletin. Article in press: doi:10.1016/j.marpolbul.2015.04.006

Santavy D.L., E.C. Peters, C. Quirolo, J.W. Porter, C.N. Bianchi. 1997. Yellowblotch disease outbreak on reefs of the San Blas Islands, Panama. Coral Reefs. 18:19

Seveso D., S. Montano, G. Strona, I. Orlandi, M. Vai, P. Galli. 2012. Up-regulation of Hsp60 in response to skeleton eroding band disease but not by algal overgrowth in the scleractinian coral Acropora muricata. Marine Environmental Research.78:3439.doi:10.1016/j.marenvres.2012.03.00 8.

Snedaker S.C. 1995. Mangroves and climate change in the Florida and Caribbean region: scenarios and hypotheses. In 
Asia-Pacific Symposium on Mangrove

Ecosystems (pp. 43-49).Springer

Netherlands.

Suharsono 1999.Condition of coral reef ressources in Indonesia. Oceanology Research and Development center (Pusat Penelitian dan Pengembangan Oseanologi-LIPI).

Tanaka Y., M. Inoue, T. Nakamura, A. Suzuki, K. Sakai. 2014. Loss of zooxanthellae in a coral under high seawater temperature and nutrient enrichment. Journal of Experimental Marine Biology and Ecology. $\quad 457, \quad 220-225$.doi: 10.1016/j.jembe.2014.04.019.

Thurber R.L.V., K.L. Barott, D. Hall, H. Liu , B. Rodriguez-Mueller, C. Desnues, F.L. Rohwer . 2008. Metagenomic analysis indicates that stressors induce production of herpes-like viruses in the coral Porites compressa. Proceedings of the National Academy of Sciences. PNAS. 105(47):1841318418.doi:10.1111/j.14622920.2009.01935.x.

Tomascik T,. A.J. Mah, A. Nontji, M.K. Moosa. 1997. The Ecology of the Indonesian Seas. Part One. The Ecology of Indonesia Series Vol.VII.

Ward-Paige C.A., M.J. Risk, O.A. Sherwood, and W.C. Jaap. 2005. Clionid sponge surveys on the Florida Reef Tract suggest land-based nutrient inputs. Marine Pollution Bulletin. 51(5):570579. doi:10.1016/j.marpolbul.2005.04.006.

Weber M., D.D. Beer, C. Lott, L. Polerecky, K. Kohls, R.M.M. Abed, T.G. Ferdelman, K.E. Fabricius. 2012. Mechanismsof damage to coral exposes to sedimentasi.PNAS.109(14):E1558/E15 67.doi:10.1073/pnas.1100715109/DCS upplemental.

Wilkinson C. 2008. Status of coral reefs of the world: 2008. Global Coral Reef Monitoring Network and Reef and Rain forest Research Centre, Townsville, Australia. 296 p.

WorkT.M.,G.S. Aeby .2011. Pathology of tissue loss (white syndrome) in Acropora sp. corals from the Central Pacific.Journal of invertebrate pathology, 107(2):127131. doi:10.1016/j.jip.2011.03.009.
YeeS.H., D.L. Santavy,M.G. Barron. 2008. Comparing environmental influences on coral bleaching across and within species using clustered binomial regression. Ecological Modelling, 218(1):162-174. doi:10.1016/j.ecolmodel.2008.06.037.

Yee S.H., D.L. Santavy, M.G. Barron. 2011. Assessing the effects of disease and bleaching on Florida Keys corals by fitting population models to data. Ecological Modelling. 222(7):13231332. doi:10.1016/j.ecolmodel.2011.01.009.

Zamani N.P. 2015. Abundance of Acanthaster Planci As Health Of Coral Indicator In Tunda Island, Serang Regency, Banten. Jurnal Ilmu dan Teknologi Kelautan Tropis, 7(1):273-286. 